\title{
Increased transcapillary escape rate of albumin in Type 1 (insulin-dependent) diabetic patients with microalbuminuria
}

\author{
B. Feldt-Rasmussen \\ Steno Memorial Hospital, Gentofte, Denmark
}

Summary. The transcapillary escape rate, intravascular mass and outflux of albumin were measured in 75 Type 1 (insulindependent) diabetic patients. The groups were defined as: group 1: normal urinary albumin excretion, $<30 \mathrm{mg} / 24 \mathrm{~h}$ $(n=21)$; group 2: microalbuminuria, $\quad 30-300 \mathrm{mg} / 24 \mathrm{~h}$ $(n=36)$; group 3: diabetic nephropathy, $<300 \mathrm{mg} / 24 \mathrm{~h}$ $(n=18)$. Fifteen sex- and age-matched non-diabetic persons served as control subjects. The diabetes duration was: group 1: $20 \pm 9$ years, group 2: $17 \pm 5$ years, group 3: $19 \pm$ 7 years. The transcapillary escape rate of albumin was similar in controls and group $1(5.0 \pm 1.8$ versus $5.2 \pm 1.5 \%)$ and was significantly higher in the microalbuminuric group 2 and group $3(8.1 \pm 2.2$ versus $8.1 \pm 2.3 \%)$. The differences were not explained by differences in metabolic control or blood pressure at the time of investigation. The outflux of albumin was also higher in group 2 than in group 1 and controls $(7.1 \pm 2.0$ versus $5.3 \pm 1.5$ and $5.1 \pm 2.0 \mathrm{~g} / \mathrm{h} \times 1.73 \mathrm{~m}^{2}$ ). It was indistinguishable from controls in group $3\left(5.8 \pm 1.5 \mathrm{~g} / \mathrm{h} \times 1.73 \mathrm{~m}^{2}\right)$ because of a reduced intravascular mass of albumin $(p<0.01)$ in group 3. In conclusion, a universal vascular leakage of albumin is an early event in the development of diabetic nephropathy, with the leakage of albumin being fully developed in the microalbuminuric patient. In contrast, long-term diabetic patients with normal urinary albumin excretion have a normal transcapillary escape rate of albumin.

Key words: Type 1 (insulin-dependent) diabetes, microalbuminuria, transcapillary escape rate, plasma volume, intravascular mass of albumin.
Increased transglomerular passage of plasma proteins as demonstrated by the presence of more than $0.5 \mathrm{~g}$ protein in 24-h urine is the diagnostic marker of clinical diabetic nephropathy. Preceding this stage, i.e. in the stage of incipient diabetic nephropathy, the urinary albumin excretion rate (UalbV) is slightly elevated (30-300 $\mathrm{mg} / 24 \mathrm{~h}$, Albustix negative), but these patients are at high risk for later development of clinical diabetic nephropathy [1-4]. The pathophysiological basis for the slightly elevated urinary albumin escape seen in early diabetic renal disease has been debated intensively. It is usually ascribed to abnormalities located specifically in the kidneys - haemodynamic alterations $[5,6]$ and/or alterations in the properties of the glomerular filter [7, 8]. However, these changes might not be restricted to the kidneys. Indications of more generalized alterations in the transcapillary passage of small molecules [9] and of macromolecules [10-12] in patients with diabetic microangiopathy have been presented. In previous studies the transcapillary escape rate of albumin $\left(\mathrm{TER}_{\mathrm{alb}}\right)$ was found to be normal in short-term diabetic patients, but elevated in patients with clinical signs of microangiopathy or arterial hypertension [10-12].
In the present study the $\mathrm{TER}_{\mathrm{alb}}$ was investigated in long-term Type 1 (insulin-dependent) diabetic patients with different levels of UalbV (normal range to overt diabetic nephropathy) as well as in normal controls.

The aim was to investigate whether a generally increased passage of albumin (i.e. TER $\mathrm{Tlb}_{\mathrm{alb}}$ ) is the result of diabetes duration alone or whether it is more specifically connected to the early or late development of diabetic nephropathy (i. e. the level of UalbV) in Type 1 patients.

\section{Subjects and methods}

\section{Subjects}

Seventy-five Type 1 patients with a diabetes duration of more than five years were studied. They had no history of non-diabetic renal or cardiac disease, and all had a negative bacterial culture of the urine. Fifteen healthy non-diabetic persons served as controls. All subjects gave their informed consent for participation, and the study was approved by the Regional Ethics Committee. The patients were subdivided into three groups according to the level of albuminuria identified on the basis of the median UalbV in three 24-h urine collections performed at home during normal physical activity. This was done in 


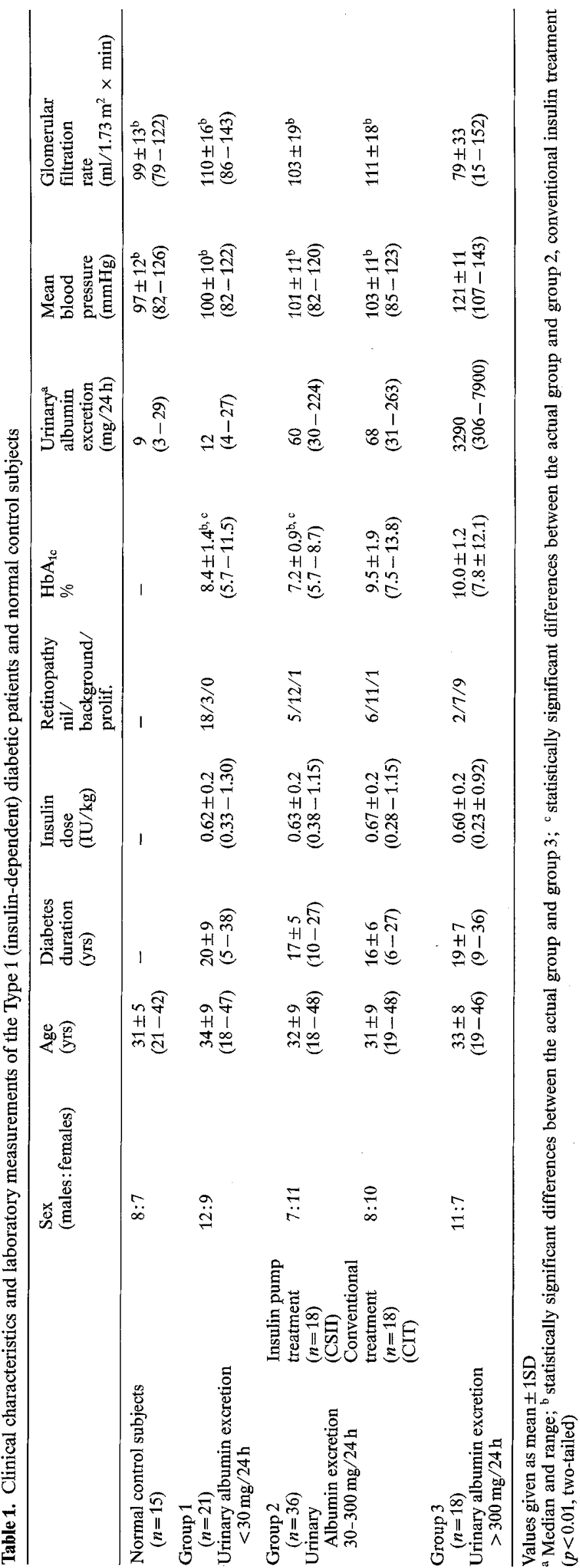

order to take into account the high (50\%) day to day variation of the $24 \mathrm{~h}$ UalbV [13]. Normal controls delivered one 24-h urine.

The three groups were defined as follows:

Group 1: 21 Type 1 patients with normal UalbV, below $30 \mathrm{mg} / 24 \mathrm{~h}$, and with blood pressure below $160 / 95 \mathrm{mmHg}$.

Group 2: 36 Type 1 patients with elevated UalbV in the range of $30-300 \mathrm{mg} / 24 \mathrm{~h}$, i. e. the patients with incipient diabetic nephropathy.

Twelve months prior to the study these patients had entered a clinical trial of the effect on the UalbV of improved metabolic control using portable insulin pumps (CSII) versus conventional insulin treatment (CIT) as previously described [14].

Group 3: 18 Type 1 patients with diabetic nephropathy (UalbV > $300 \mathrm{mg} / 24 \mathrm{~h}$ ). Any ongoing antihypertensive treatment had been discontinued for 8 weeks except in two patients receiving diuretics due to mild oedema.

The clinical characteristics of patients and controls are shown in Table 1. A close match of sex distribution, age and diabetes duration was obtained.

The patients in group 1 and 3 and the CIT group received conventional insulin treatment, i.e. 2-3 daily injections of intermediate -acting insulin often mixed with short-acting insulin.

\section{Methods}

The transcapillary escape rate of albumin was measured as described by Parving [15]. The investigations were carried out in the morning preceded by a normal breakfast and insulin injection at home. A canulla was inserted in the antecubital vein in each arm, and the patients had rested for $60 \mathrm{~min}$ in the supine position. ${ }^{125} \mathrm{I}$-human serum albumin (Code IFA-IT23S, Kjeller, Oslo, Norway) was used.

After intravenous injection of the tracer $(2 \mu \mathrm{Ci})$ in one arm, 7 blood samples were collected from the other arm during the first hour. Plasma radioactivity was measured in each sample using a well-type scintillation detector and expressed as $\mathrm{cpm} / \mathrm{g}$ total plasma protein. These ratios were plotted in semilogarithmic scale, and the transcapillary escape rate was calculated as the disappearance rate constant. Thus, the TER $\mathrm{R}_{\mathrm{abb}}$ is the fraction of the intravascular mass of albumin leaving the vascular bed per hour $(\% / h)$.

Plasma volume (PV, $\mathrm{ml} / 1.73 \mathrm{~m}^{2}$ ) was determined by retropolation of the disappearance curve to zero time and from the injected volume of tracer.

The glomerular filtration rate (GFR) was measured with single intravenous injection of ${ }^{51} \mathrm{Cr}$ EDTA, plotting the plasma disappearance of the tracer for $4 \mathrm{~h}$ [16]. The mean intraindividual coefficient of variation was $4.1 \%$

Serum albumin (g/l) was measured using an ELISA assay [13]. The interassay variation was $8.3 \%$. From these determinants the intravascular mass of albumin and the outflux of albumin per hour were calculated.

Intravascular mass of albumin (IVM) was calculated as plasma volume times s-albumin $\left(\mathrm{g} / 1.73 \mathrm{~m}^{2}\right)$.

Outflux of albumin was calculated as IVM times $\mathrm{TER}_{\mathrm{alb}}(\mathrm{g} / \mathrm{h} \times$ $\left.1.73 \mathrm{~m}^{2}\right)$.

The urinary albumin excretion was measured using an ELISA-assay [13].

$H b A_{I c}$ was measured by a chromatographic technique [17]. The normal range was $4.1-6.4 \%$.

S-creatinine was measured by a reaction rate kinetic principle eliminating pseudo-creatinines [18]. The interassay variation was $2.5 \%$. 
B-glucose was measured three times during the study using Hypocount (Suffolk, UK).

\section{Statistical analysis}

Results are given as mean \pm SD. The paired and unpaired Student's ttests were used for comparisons within and between groups. UalbV values were log-transformed before calculations. Significance levels were 0.05 (two-tailed).

\section{Results}

The TER $\mathrm{Talb}_{\mathrm{b}}$ was similar in normal controls and group 1 (Fig. 1). It was significantly higher in group 2 patients with incipient nephropathy $(p<0.01)$, and the mean $\mathrm{TER}_{\mathrm{alb}}$ of group 2 and 3 was identical (Fig. 1). There was no significant correlation between $T_{E R}$ alb and age or TER $R_{\mathrm{alb}}$ and UalbV in any of the groups.

The blood pressure was higher and the GFR was lower in group 3 compared with the other three groups (Table 1). The long-term metabolic control $\left(\mathrm{HbA}_{1 \mathrm{c}}\right)$ was worse in group 3 compared with the other groups (Table 1). B-glucose on the day of study was found to be significantly higher $(p<0.01)$ in this group compared with group 1 (Table 2). However, in group 2 the 18 conventionally treated patients had similar metabolic control, whereas the 18 insulin pump treated patients were in a significantly $(p<0.01)$ better metabolic state (Tables 1 and 2). This difference in metabolic control was not reflected in different levels of TER $\mathrm{alb}_{\mathrm{b}}$ within group 2 (CSII vs. CIT, Fig. 1).

S-albumin was significantly lower in the conventionally insulin-treated patients in group 2 compared with the normoalbuminuric group 1 and normal con-

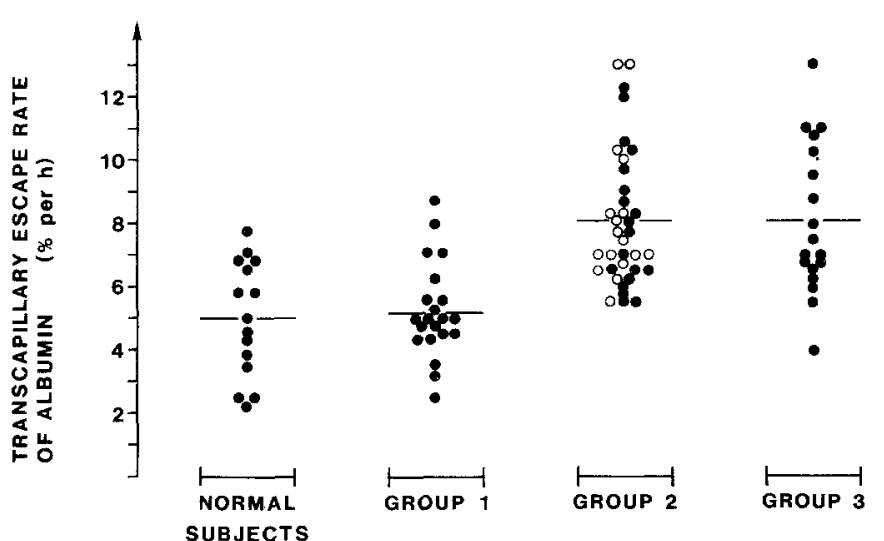

Fig.1. The transcapillary escape rate of albumin in Type 1 (insulindependent) diabetic patients with different levels of urinary albumin excretion. Group $1(n=21)$ : Normal urinary albumin excretion < $30 \mathrm{mg} / 24 \mathrm{~h}$. Group $2(n=36)$ : Incipient diabetic nephropathy, i. e. urinary albumin excretion from $30-300 \mathrm{mg} / 24 \mathrm{~h}$. Group $3(n=18)$ : Diabetic nephropathy, i.e. urinary albumin excretion $>300 \mathrm{mg} / 24 \mathrm{~h}$. Horizontal bars indicate mean values. $\sim$ Conventional insulin treatment. $O \sim$ Continuous subcutaneous insulin infusion (CSII) for 12 months. The values in group 2 and 3 are significantly higher than in normal controls and group $1(p<0.01)$

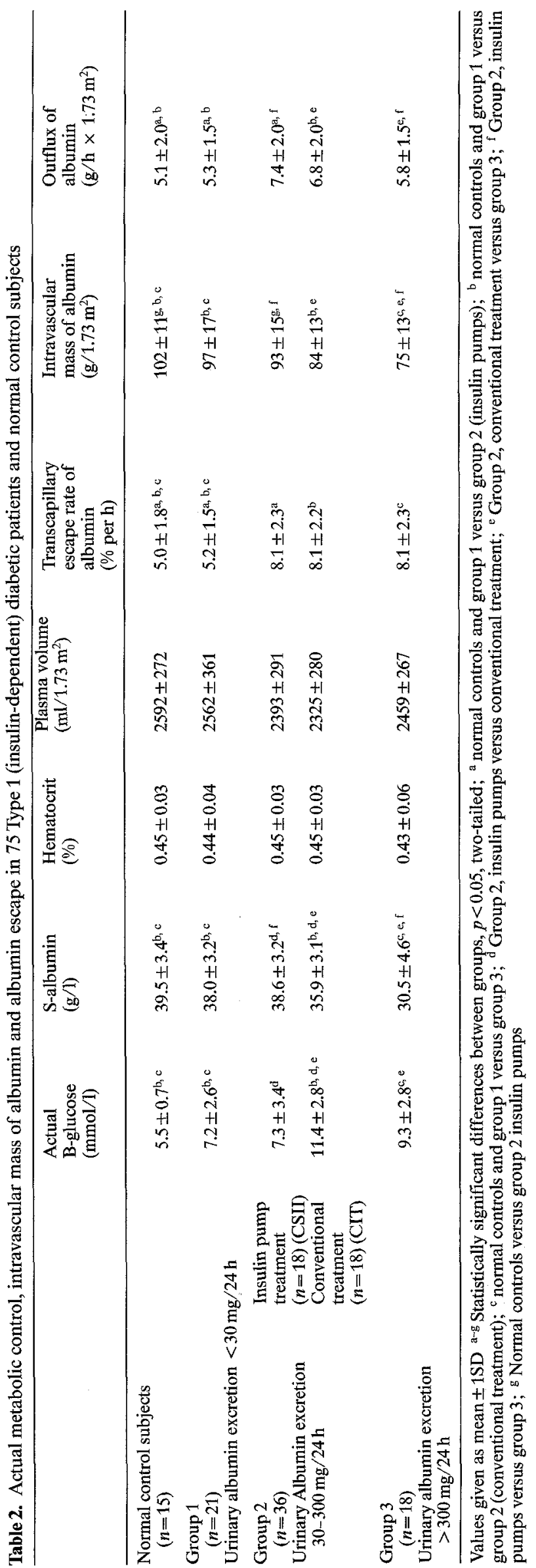


trols, and even lower in group 3 ( $p<0.05$, Table 2$)$. The plasma volume was similar in all groups, with a tendency to lower values in group 2 (all 36 patients, $p<0.05$ ) and, in consequence, the intravascular mass of albumin was significantly reduced in the groups with lower S-albumin (Table 2). The outflux of albumin in group 3 was indistinguishable from normal controls and group 1 in

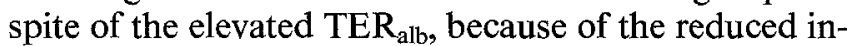
travascular mass of albumin.

\section{Discussion}

This study has shown that the TER $\mathrm{R}_{\mathrm{alb}}$ is normal in longterm diabetic patients with normal UalbV. It has also shown that the TER $\mathrm{alb}_{\mathrm{b}}$ is elevated to the same level in patients with microalbuminuria and in patients with overt clinical diabetic nephropathy. This observation corroborates the hypothesis that there may be a ceiling for the maximum rate of escape of albumin from the circulation [11]. Increased values of $\mathrm{TER}_{\mathrm{alb}}$ have been demonstrated previously in long-term diabetic patients with various degrees of microangiopathy and normal blood pressure [10-12], and a normal TER $\mathrm{Tlb}_{\mathrm{b}}$ has been found in short-term diabetic patients without microangiopathy $[10,11]$. However, our observation of a bimodal distribution of the TER $\mathrm{alb}_{\mathrm{b}}$ in long-term diabetic patients with Albustix negative urine, but different albuminuric levels, is new.

The groups were well-matched according to sex, age and diabetes duration. The diabetes duration was as long or even longer than in previous studies of $T E R_{a l b}$ and long-term diabetes [10-12]. The TER $\mathrm{R}_{\mathrm{alb}}$ is elevated in patients with arterial hypertension [11, 15], and the blood pressure has been reported to be slightly elevated in diabetic patients with microalbuminuria [19-21]. However, before entrance into this study, group 2 patients with resting blood pressure higher than $160 / 95 \mathrm{mmHg}$ were excluded; therefore, the mean blood pressure was the same in group 1 and 2 and thus could not account for the elevated $\mathrm{TER}_{\text {alb }}$ in the microalbuminuric group 2. Improved metabolic control reduces the $T E R_{a b b}$ in poorly regulated short-term diabetic patients, insulin-dependent [22] as well as non-insulin-dependent [11]. Differences in metabolic control at the time of investigation could not explain the observed differences in TER $\mathrm{alb}_{\mathrm{alb}}$ in this study, because the metabolic control on the day of study was similar in group 1 and the insulin pump treated group 2 patients. Furthermore, the $\mathrm{TER}_{\mathrm{alb}}$ was unchanged during 12 months of strict metabolic control (data not shown). This is in contrast to what was found in short-term insulin-dependent diabetic patients [22]. Therefore, the metabolically independent elevation of TER $\mathrm{alb}_{\mathrm{ab}}$ seen in the microalbuminuric group 2 patients may be a marker of a more fundamental structural microvascular lesion, leading to the clinical manifestation of diabetic microangiopathy. The actual outflux of albumin from the vas- cular bed was higher in the microalbuminuric group 2 compared with normal controls and group 1 in spite of a decreased intravascular mass of albumin in group 2. In group 3 (diabetic nephropathy) an outflux of albumin was found indistinguishable from normal controls and group 1 . This was due to a lower intravascular mass of albumin in these patients.

The reduced intravascular mass of albumin found in groups 2 and 3 will result in a decreased, intravascular colloid osmotic pressure which might lead to the oedema often found in patients with diabetic nephropathy. However, the interstitial colloid osmotic pressure was not measured in this study.

The significance of an increased outflux of proteins is unknown, but it might be an important mechanism in the development of diabetic microangiopathy $[8,23]$. The coincident observation of microalbuminuria and increased $\mathrm{TER}_{\mathrm{alb}}$ may indicate that the structural and/ or haemodynamic abnormalities underlying the increased escape of albumin in the glomerular and extrarenal capillaries are the same. These abnormalities seem to be absent in long-term diabetic patients with normal UalbV, possibly explaining the almost normal life expectancy of Type 1 patients who do not develop proteinuria [24]. The structural abnormalities are probably different from what is classically described as diabetic microangiopathy, since in group 2 the increased UalbV and $T E R_{a l b}$ were observed in many patients, even before microaneurisms had appeared. Furthermore, the UalbV was found normal in many long-term diabetic patients, demonstrating glomerulosclerosis and increased thickness of the glomerular basement membrane [25].

In conclusion, long-term diabetic patients with nor-

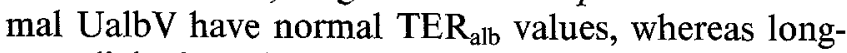
term diabetic patients with persistent microalbuminuria have an increased TER $\mathrm{Tlb}_{\mathrm{ab}}$, independent of current metabolic control and blood pressure. These patients also demonstrate a decreased intravascular mass of albumin. Thus, microalbuminuria indicates profound alterations in Type 1 patients, and these alterations might be crucial in the development of lethal diabetic complications.

Acknowledgements. This work was supported by grants from the $\mathbf{J}$ and O Juhls Foundation, the Michaelsen Foundation, Diabetesforeningen, Landsforeningen for Sukkersyge and the Danish Medical Research Foundation. Ms. M. Deckert and Ms. H. Foght are thanked for their skillful technical assistance.

\section{References}

1. Parving H-H, Oxenbøll B, Svendsen PAa, Christiansen JS, Andersen AR (1982) Early detection of patients at risk of developing diabetic nephropathy. A longitudinal study of urinary albumin excretion. Acta Endocrinol 100: 550-55

2. Viberti GC, Hill RD, Jarrett RJ, Argyropoulos A, Mahmud U, Keen H (1982) Microalbuminuria as a predictor of clinical nephropathy in insulin-dependent diabetes mellitus. Lancet 1: $1430-32$ 
3. Mathiesen ER, Oxenbøll B, Johansen K, Svendsen PAa, Deckert $T$ (1984) Incipient nephropathy in Type 1 (insulin-dependent) diabetes. Diabetologia 26: 406 -10

4. Mogensen CE, Christensen CK (1984) Predicting diabetic nephropathy in insulin-dependent patients. N Engl J Med 311: 89-93

5. Hostetter TH, Rennke HG, Brenner BM (1982) The case for intrarenal hypertension in the initiation and progression of diabetic and other glomerulopathies. Am J Med 72: 375-383

6. Parving H-H, Viberti GC, Keen H, Christiansen JS, Lassen NA (1983) Hemodynamic factors in the genesis of diabetic microangiopathy. Metabolism 32: 943-49

7. Mauer SM, Steffes MW, Goetz FC, Sutherland DER, Brown DM (1983) Diabetic nephropathy. A perspective. Diabetes Suppl 2: $52-55$

8. Deckert T, Feldt-Rasmussen B, Mathiesen ER, Baker L (1984) Pathogenesis of incipient nephropathy: a hypothesis. Diabetic Nephropathy 3: 83-88

9. Trap-Jensen J (1971) Permeability of small vessels in diabetes. Acta Diabet Lat 8 (Suppl 1): 192-200

10. Parving H-H, Munkgaard Rasmussen S (1973) Transcapillary escape rate of albumin and plasma volume in short- and long-term juvenile diabetes. Scand J Clin Lab Invest 32: 81-7

11. O'Hare JA, Ferris JB, Twomey B, O’Sullivan DJ (1983) Poor metabolic control hpyertension and microangiopathy independently increase the transcapillary rate of albumin in diabetes. Diabetologia $25: 260-63$

12. Fauchald P, Norseth J, Jervell J (1985) Transcapillary colloid osmotic gradient, plasma volume and interstitial fluid volume in long-term type 1 (insulin-dependent) diabetes. Diabetologia 28: $269 \cdots 73$

13. Feldt-Rasmussen B, Dinesen B, Deckert M (1985) Enzyme immuno assay - an improved determination of urinary albumin in diabetics with incipient nephropathy. Scand J Clin Lab Invest 45 : $539-44$

14. Feldt-Rasmussen B, Mathiesen ER, Hegedus L, Deckert T (1986) Kidney function during 12 months of strict metabolic control in insulin dependent diabetic patients with incipient nephropathy. N Engl J Med 314: 665-70

15. Parving H-H, Gyntelberg F (1973) Transcapillary escape rate of albumin and plasma volume in essential hypertension. Cir Res 32: $643-51$
16. Bröchner-Mortensen J, Giese J, Rossing N (1969) Renal inulin clearance versus total plasma clearance of ${ }^{51} \mathrm{Cr}$-EDTA. Scand $\mathbf{J}$ Clin Lab Invest 23: 301-5

17. Svendsen PAa, Christiansen JS, Søegaard U, Welinder BA, Nerup J (1980) Rapid change in chromatographically determined haemoglobin $A_{1 c}$ induced by short-term changes in glucose concentration. Diabetologia 19:130-36

18. Larsen K (1972) Creatinine assay by a reaction-kinetic principle. Clin Chim Acta 41: 209-17

19. Wiseman M, Viberti GC, Mackintosh D, Jarret RJ, Keen H (1984) Glycaemia, arterial pressure and microalbuminuria in type 1 (insulin-dependent) diabetes mellitus. Diabetologia 26: 401-5

20. Feldt-Rasmussen B, Borch-Johnsen K, Mathiesen ER (1985) Hypertension in diabetes as related to nephropathy. Early bloodpressure changes. Hypertension 7 (Suppl II): 18-20

21. Feldt-Rasmussen B, Baker L, Deckert T (1985) Excercise as a provocative test in early renal disease in type 1 (insulin-dependent) diabetes: albuminuric, systemic and renal haemodynamic responses. Diabetologia 28:389-96

22. Parving H-H, Noer I, Deckert T, et al (1976) The effect of metabolic regulation of microvascular permeability to small and large molecules in short term juvenile diabetes. Diabetologia 12: 161-66

23. Lendrum AC (1963) The hypertensive diabetic kidney as a model of the so-called collagen disease. Can Med Assoc J 88: 442-52

24. Borch-Johnsen K, Kragh Andersen P, Deckert T (1985) The effect of proteinuria on relative mortality in Type 1 (insulin-dependent) diabetes mellitus. Diabetologia 28:590-96

25. Mauer SM, Steffes MW, Ellis EN, Sutherland DER, Brown DM, Goetz FC (1984) Structural-functional relationships in diabetic nephropathy. J Clin Invest 74: 1143-45

Received: 24 October 1985

and in revised form: 3 February 1986

Dr. B. Feldt-Rasmussen

Steno Memorial Hospital

DK-2820 Gentofte

Denmark 